\title{
Consumers' Subjective and Objective Knowledge Levels About Genetically Modified Foods: Case Study of Hatay City
}

\author{
Ahmet Duran Çelik, Erdal Dağıstan \\ Department of Agricultural Economics, Faculty of Agriculture, Mustafa Kemal University, 31100 Hatay, Turkey
}

\section{A R T I C LE INFO}

\section{Research Articles}

Received 06 March 2018

Accepted 02 July 2018

Keywords:

Genetically modified foods

Objective

Subjective

Knowledge

Hatay

${ }^{*}$ Corresponding Author:

E-mail: acelik_01@hotmail.com

\begin{abstract}
A B S T R A C T
The relationship between an individual's actual knowledge and their self assessed knowledge about an issue is an important factor on consumer's behaviour. The effect of the knowledge factor on consumer decision making is evaluated by two approaches which are objective (real knowledge) and subjective (self assessed) knowledge. In certain studies it was found that in some situations consumers believe they know more than they actually do about a topic; and they may make their decisions based upon the knowledge they assume is correct, whether it is true or not. This study aimed at determining the relationship between the objective and subjective knowledge about GM foods of consumers who live in the Hatay city centre. According to the research results; even though around $70 \%$ of the consumers thought that their knowledge about GM foods were "'enough, or relatively enough", correct response ratios of the four questions that were based on specific knowledge were quite low. In other words, consumers were overconfident about their knowledge of GM foods. Also, there was no correlation found between consumer's purchase intention and knowledge level.
\end{abstract}

Tüketicilerin Genetiği Değiştirilmiş Ürünler Hakkında Objektif ve Subjektif Bilgi Seviyeleri: Hatay İli Örneği

M A K A L E B İ L G İ S İ

\section{Araştırma Makalesi}

Geliş 06 Mart 2018

Kabul 02 Temmuz 2018

Anahtar Kelimeler:

Genetiği değiştirilmiş ürünler

Objektif

Subjektif

Bilgi

Hatay

"Sorumlu Yazar:

E-mail: acelik_01@hotmail.com

\section{Ö Z}

Bireylerin bir ürün hakkındaki gerçek bilgileriyle, kendi öz değerlendirmeleri sonucu doğru varsaydıkları bilgi arasındaki ilişki, tüketici davranışları üzerinde belirleyici rol oynayan bir faktördür. Bilgi faktörünün karar verme davranışı üzerine etkisi objektif (gerçek) ve sübjektif (kişisel değerlendirme) olmak üzere iki yaklaşımla ölçülmektedir. Bugüne kadar yapılan pek çok araştırmada, tüketicilerin belirli konu hakkında kendilerini olduklarından daha bilgili gördükleri ve bireysel olarak doğru olduğuna inanılan bu bilgi doğrultusunda karar verdikleri ortaya konulmuştur. Bu çalışmada, Hatay ili Antakya ilçe merkezinde yaşayan tüketicilerin, genetiği değiştirilmiş ürünler hakkındaki objektif ve sübjektif bilgileri arasındaki ilişki ortaya konulmaya çalışılmıştır. Araştırma sonuçlarına göre; tüketicilerin yaklaşık \%70'i kendilerini genetiği değiştirilmiş ürünler hakkında '"kısmen veya yeterli bilgiye sahip" olarak değerlendirirken, objektif bilgilerini ölçemeye yönelik sorulan 4 soruya doğru cevap verme oranı oldukça düşük kalmıştır. Başka bir deyişle, araştırmada tüketicilerin GD ürünler hakkında kendilerini olduklarından daha bilgili buldukları sonucuna ulaşılmıştır. Ayrıca araştırmada, tüketicilerin genetiği değiştirilmiş ürünler hakkındaki objektif ve sübjektif bilgileri ile satın alma niyetleri arasında anlamlı bir ilişki olmadığı sonucuna ulaşılmıştır. 


\section{Introduction}

Genetically Modified (GM) foods have been a controversial topic since the beginning, and there were many studies carried out about different aspects of the issue. Some scientiests defend genetic modification in food products claming that traditional farming methods don't meet the food needs of the growing global population, and that genetically modified products could be the solution for that by increasing productivity. However, some other scientists drew attention to the fact that while some countries are suffering from famine, others are struggling with obesity. Therefore, the reasons for food shortages are not only about global population growth, but also about its imbalanced food distribution (Akgönül et al., 2009).

In terms of health concerns, there were also some controversial studies. In a study that was carried out by Denison (1999) in England, it was stated that there have been increases in allergic diseases derived from consuming genetically modified soybeans. In another study carried out by Chang and Huang (2010), it was stated that there is no more risk in GM foods than in foods that are grown by traditional methods.

Knowledge level is one of the most important determinants on consumers' GM food acceptance, and there have been many studies about consumers' knowledge levels. In a study that was carried out by House et.al (2004), it was found that consumers' acceptance levels of GM foods increased along with their knowledge levels. Klerck and Sweeney (2007) stated that consumers' knowledge levels about GM foods have an important influence on their behaviors and risk perceptions, and that risk perceptions decreased as consumer knowledge levels increased. Laros \& Steenkamp (2004) found that fear about GM foods occured emotionally in society, is independent from socio-demografic factors.

In terms of Turkey, there are previous studies about consumers' knowledge levels regarding GM foods. Some of those studies indicate that consumers don't have sufficient knowledge about GM foods. There are some consumers who are misinformed and think they are consuming GM products on the market; however, it's legally forbidden to produce or import GM products in Turkey (Anonymous, 2014). In a study that was carried out by Koçak et al. (2010) among medical students, it was found that $72 \%$ of the students didn't have sufficient knowledge about GM products. Karlı et al. (2008) found that people with higher educations are more willing to pay for GM foods.

In some specific cases, consumers found themselves to be more knowlegeable than they really are (Alba and Hutchinson, 2000). In this context, the effect of knowledge on decision making is measured with two main approaches (Park and Lessig, 1981); in the first approach, consumers' actual knowledge about an issue is measured (objective knowledge), in the second approach, how much consumers think that they know about the issue is measured (subjective knowledge). Objective and subjective knowledge usually differ from each other. In the case where consumers don't comprehend their knowledge level about an issue, this situation could play a determining role on their behaviours (Brucks, 1985; Selnes and Gronhaug, 1986).
Aertsens et al. (2010) carried out a study about the effects of subjective and objective knowledge on consumers' behaviours towards organic foods. According to the research results, consumers with a high level of objective and subjective knowledge had positive opinions about organic foods. It was also found that especially objective knowledge had a positive and direct influence on consumers' behaviours.

A study that was carried out by Knight (2005), found that consumers' self assessments (subjective) of their knowledge had more influence than their actual knowledge (objective) on their behaviours towards GM foods. Also, it was found that moral and ethical values, and social environment were other determinants on consumers' GM food perceptions. Whether true or false, consumers' self assessments had a bigger influnce on their behaviours regarding GM foods.

In another study carried out by Hallman et al. (2003), it was found that consumers exaggerate their knowledge about GM foods, and their real level of knowledge was less than their self assessments. While most of the consumers defined their level of knowldge about the topic as 'good", only $5 \%$ of them responded correctly to all 7 knowledge based questions.

The purpose of this study is examining the differences between consumers' objective and subjective knowledge levels, and researching the effects of those differences on their acceptance of GM foods.

\section{Materials and Methods}

\section{Materials}

Parent material of this study consisted of primary data that were obtained by the face-to-face interview method from consumers who lived in the city center of Hatay. Also, secondary data were obtained from previous studies about the topic.

\section{Methods}

Simple Random Sampling Method was used in order to determine the sample size. In the sampling, $\mathrm{P}$ and $\mathrm{Q}$ values were determined as 0.50 , and sample size was found as 266 at a $95 \%$ level of significance and at a $6 \%$ error margin. The formula of the method (Churchill, $1995)$ is given below;

$$
n=\left(\frac{Z_{x / 2}}{d}\right)^{2} P \cdot Q
$$

$P$ : Positive probability $(50 \%)$

$Q: 1-P$ Negative probability

$Z_{x / 2}$ : Confidence interval (\%95, table value 1.96$)$

$d$ : Error margin (\%6).

$$
n=\left(\frac{1.96}{0.06}\right)^{2} 0.50 * 0.50=266
$$

Within the study, 300 surveys were carried out, and 270 of them were taken into consideration after excluding the insufficient ones. The primary data gathered from the consumers who lived in the city center of Hatay, were analyzed by means of the SPSS 21 Statistics Software. 


\section{Data Evaluation}

Multiple correspondence analysis: Correspondence Analysis is a descriptive and multivariate analysis method which allows the comparison of variables by means of two or multi dimensional crosstabs (Kılıç, 2016). Multiple Correspondence Analysis is an extended version of the Correspondence Analysis that allows the analysis of multi categorical and dependent variables (Abdi et.al., 2007).

Theoretically, observed frequencies and observed associations of variables are presented by means of a twodimensional crosstab, so that associations of different variables at different levels could be determined. In other words, Correspondence Analysis is a geometrical method that allows presenting associations of a crosstab's rows and columns as coherent points (Uzgören, 2007).

Likert scale: The Likert Scale is being used to present the level of agreement or disagreement about a statement. There are some varieties of the Likert Scale such as 5 points, 7 points, or 9 points (Karagöz et al., 2004). The 5 point Likert Scale was used in this study to evaluate consumers' level of subjective knowledge (1=low, 5=high).

Spearman rank correlation: Correlation Analysis is a statistical analysis method used to evaluate the relationship between two variables. The Spearman Rank Correlation analysis is a highly affective method to evaluate non-parametric data. The formula to evaluate the Spearman Rank Correlation is shown below. A correlation coefficient that is approaching +1 indicates a positive and strong relationship, 0 correlation coefficient indicates there is no statistical relationship and approaching -1 indicates a negative and strong relationship (Jobson, 1991; Nakip, 2006). The Spearman Rank Correlation coefficient was used to evaluate the correlation between consumers' knowledge level and their purchase intention.

\section{Results and Discussion}

Consumers' demographic characteristics were given in Table 1. In terms of age distribution, $55 \%$ of the consumers were between 26 and 45 years old, $58 \%$ were male and $42 \%$ were female. The education levels of consumers were, $31 \%$ had high school diplomas, and $36 \%$ had university degrees (associate and undergraduates). In terms of monthly income; $56 \%$ of the consumers' incomes were between $1000 \mathrm{TL}$ and $2999 \mathrm{TL}$, and 12\% of their incomes were under 1000 TL. In terms of monthly food expenses; $40 \%$ of their monthly spending was between $250 \mathrm{TL}$ and $499 \mathrm{TL}$, and $32 \%$ of them were spending between $500 \mathrm{TL}$ and $999 \mathrm{TL}$ on food each month.

The consumers were asked, 'Do You Know What GM Food is?', (Q1), and 83\% of them stated, "Yes. I Know What GM Food is'. The second question they were asked was, 'How Much Do You Think that You Know About GM Foods?', (Q2) (Table 2).

Even though $73 \%$ of the consumers stated that they more or less know about GM foods (Table 2); the correct answer ratio of the four knowledge based statements (objective) they were asked, were quite low (Table 3).
These statements were;

OK1: Ordinary food products do not contain genes but GM foods do.

OK2: GM foods contain hormones.

OK3: By eating genetically modified food, a person's genes could also be changed.

OK4: GM foods are larger than ordinary food products.

The reliability coefficient of the analysis which is Cronbach's Alpha, was found as 0.64 (64\%), and the analysis results were found as significant at 0.000 $(<0.005)$.

The consumers were asked their opinions about 4 knowledge based statements (House, 2004) in order to examine their objective knowledge level about GM Foods (Table 3).

Table 1 Demographic characteristics of consumers (1 $\mathrm{USD}=2 \mathrm{TL}, 2013$ )

\begin{tabular}{|c|c|}
\hline Variable & Ratio (\%) \\
\hline \multicolumn{2}{|l|}{ Age } \\
\hline $16-25$ & 15.9 \\
\hline $26-35$ & 27.0 \\
\hline $36-45$ & 28.1 \\
\hline $46-55$ & 21.1 \\
\hline $56-65$ & 5.2 \\
\hline $66+$ & 2.6 \\
\hline Median (Min:1-Max:6) & 3 \\
\hline \multicolumn{2}{|l|}{ Gender } \\
\hline Female & 42.2 \\
\hline Male & 57.8 \\
\hline \multicolumn{2}{|l|}{ Education level } \\
\hline Primary & 14.1 \\
\hline Middle school & 12.2 \\
\hline High school & 30.7 \\
\hline Associate and undergraduates & 35.9 \\
\hline Postgraduates & 7.0 \\
\hline \multicolumn{2}{|l|}{ Monthly Income (TL) } \\
\hline$<1000$ & 12.2 \\
\hline 1000-1999 & 26.7 \\
\hline 2000-2999 & 29.3 \\
\hline $3000-4999$ & 21.1 \\
\hline$>5000$ & 10.7 \\
\hline Median (Min:1-Max:5) & 3 \\
\hline \multicolumn{2}{|l|}{ Monthly Food Expense (TL) } \\
\hline$<250$ & 9.6 \\
\hline $250-499$ & 40.0 \\
\hline $500-999$ & 32.2 \\
\hline $1000-1499$ & 12.2 \\
\hline$>1500$ & 5.9 \\
\hline
\end{tabular}

Table 2 Subjective knowledge (self assessed) levels of consumers about GM foods

\begin{tabular}{l|cc}
\hline \multicolumn{1}{c|}{ Q2 } & $\mathrm{F}$ & $\mathrm{R}(\%)$ \\
\hline I have no knowledge & 25 & 9.3 \\
I don't have much knowledge & 48 & 17.7 \\
I have a sufficient level of knowledge & 140 & 51.9 \\
I have a fair enough level of knowledge & 51 & 18.9 \\
I have an advanced level of knowledge & 6 & 2.2 \\
\hline Total & 270 & 100.0 \\
\hline Q2: 'How Much Do You Think that You Know About GM Foods?"
\end{tabular}
(Subjective Knowledge), F: Frequency, R: Ratio 
The consumers were asked if they agree or disagree that 'Ordinary Food Products Do not Contain Genes but GM Foods Do', (OK1/False), and $46 \%$ of them stated their disagreement with that statement. (Standard Deviation: 0.070).

Almost half of the consumers agreed with the statement that "GM Foods Contain Hormones"' (OK2/False), and only $32 \%$ of them disagreed with this statement. (Standard Deviation: 0,075). According to this result, most of the consumers didn't know the difference between GM foods and hormone injected food products.

Among the consumers; $42 \%$ of them agreed that ' $B y$ Eating Genetically Modified Foods, a Person's Genes
Could Also be Changed"' (OK3/False), 58\% of the consumers had no opinion or didn't have knowledge about the statement. (Standard Deviation: 0,062). There is no scientific evidence that verifies this statement (Hallman, et.al., 2003).

The statement that "GM Foods are Larger than Ordinary Food Products", (OK4) is a false statement (Hallman, et.al., 2003). However, almost half of the consumers agreed with that statement, and only $34 \%$ of them disagreed with it. (Standard Deviation: 0,073). Thus, it was concluded that most of the consumers didn't know another difference between GM food products and hormone injected food products.

Table 3 Distribution of consumers' objective knowledge about GM foods

\begin{tabular}{|c|c|c|c|c|c|c|c|c|}
\hline \multirow{2}{*}{$\begin{array}{c}\text { Objective } \\
\text { Knowledge }\end{array}$} & \multicolumn{2}{|c|}{ Agree } & \multicolumn{2}{|c|}{ Disagree } & \multicolumn{2}{|c|}{ Have No Opinion } & \multirow{2}{*}{$\begin{array}{l}\text { Standard } \\
\text { Deviation }\end{array}$} & \multirow{2}{*}{ Sig } \\
\hline & Frequency & Ratio (\%) & Frequency & Ratio (\%) & Frequency & Ratio (\%) & & \\
\hline OK1 & 86 & 32 & 124 & 46 & 60 & 22 & 0.070 & 0.000 \\
\hline $\mathrm{OK} 2$ & 141 & 52 & 87 & 32 & 42 & 16 & 0.075 & 0.000 \\
\hline OK3 & 113 & 42 & 67 & 25 & 90 & 33 & 0.062 & 0.000 \\
\hline $\mathrm{OK} 4$ & 131 & 49 & 92 & 34 & 47 & 17 & 0.073 & 0.000 \\
\hline
\end{tabular}

Cronbach's Alpha= 0.64, Sig: $0.000<0.005$

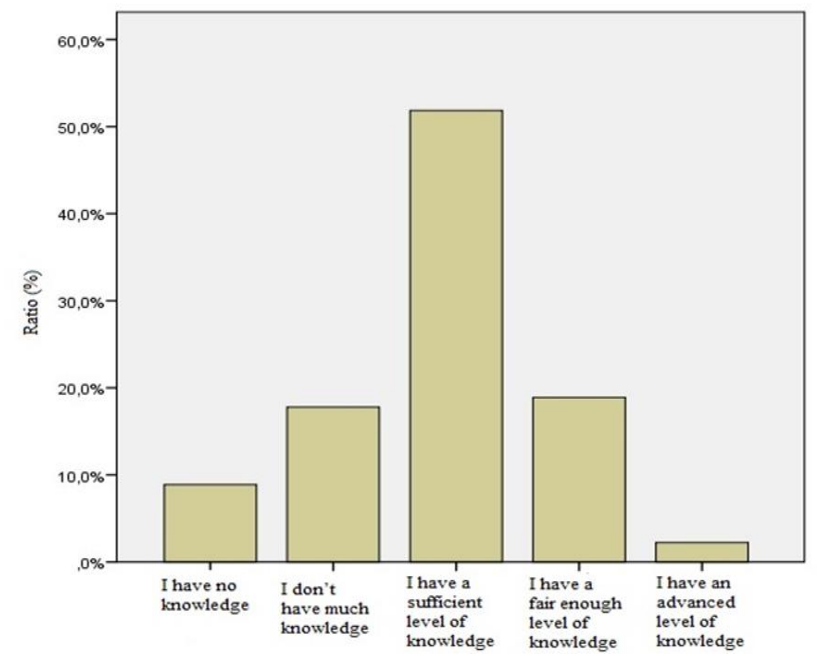

Figure 1 Subjective knowledge (self assessed) levels of consumers about GM foods

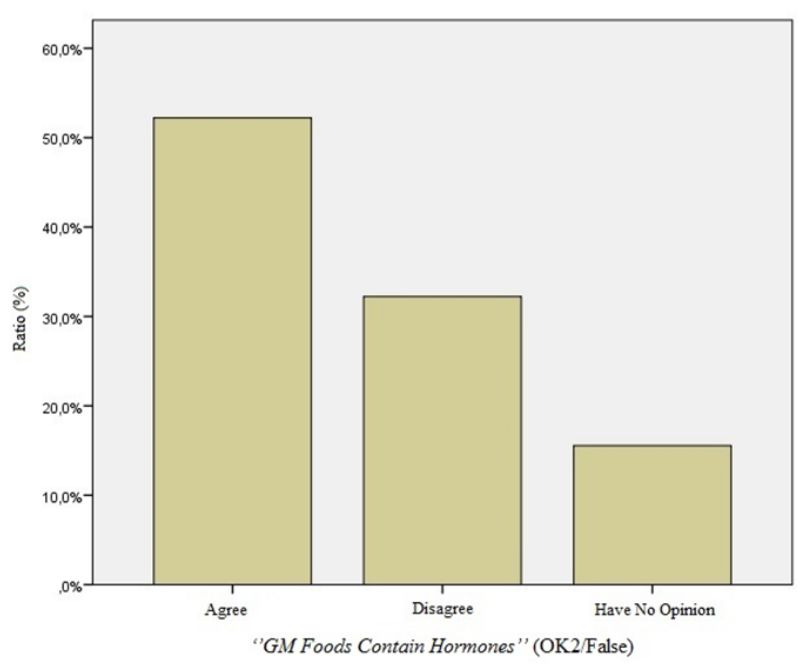

Figure 3 Consumers' Agreement Level of Objective Knowledge 2

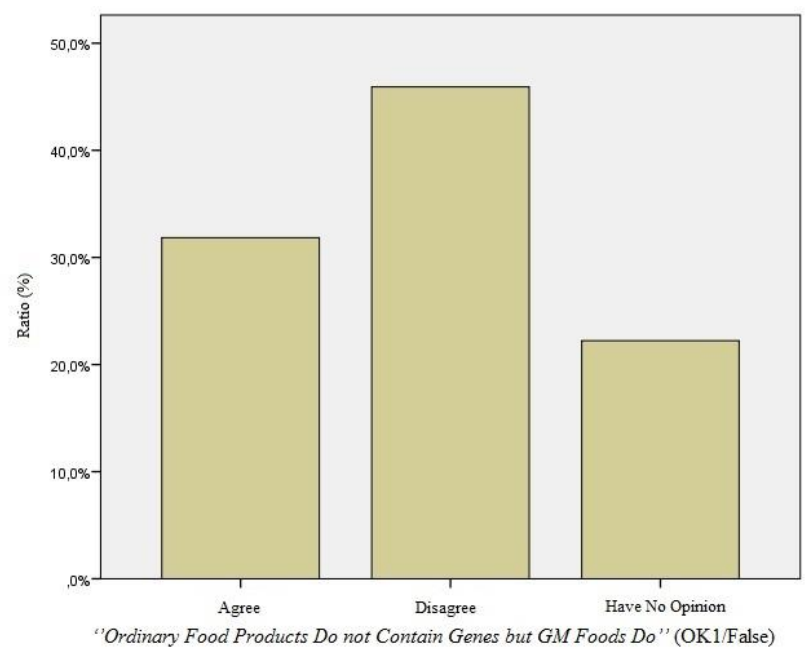

Figure 2 Consumers' Agreement Level of Objective Knowledge 1

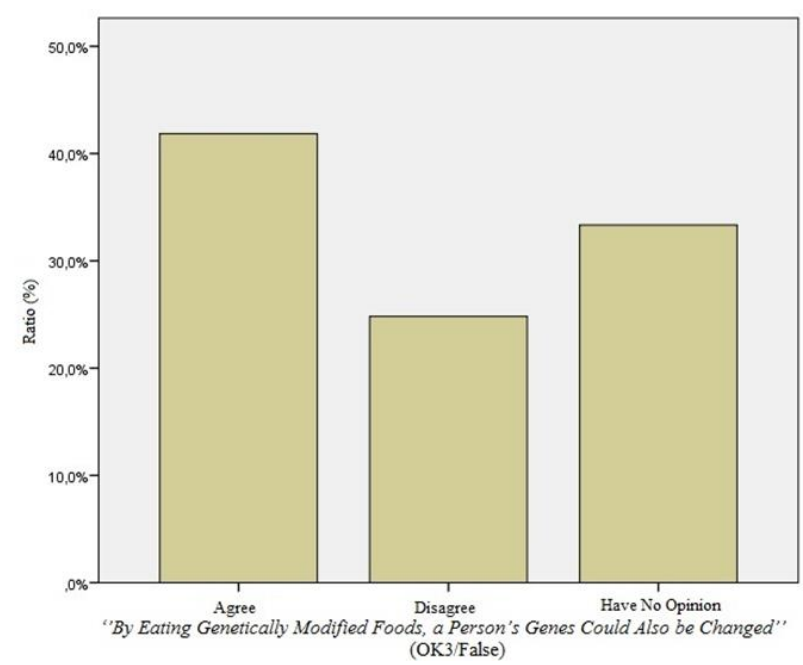

Figure 4 Consumers' Agreement Level of Objective Knowledge 3 
Table 4 Multiple correspondence table of consumers' objective and subjective knowledge

\begin{tabular}{|c|c|c|c|c|c|c|c|}
\hline \multirow{3}{*}{$\begin{array}{c}\text { Subjective } \\
\text { Knowledge } \\
\text { (Q1) }\end{array}$} & \multicolumn{7}{|c|}{ OK1 (Ordinary Food Products Do Not Contain Genes/False) } \\
\hline & \multicolumn{2}{|c|}{ Wrong Answer } & \multicolumn{2}{|c|}{ Correct Answer } & \multicolumn{2}{|c|}{ Have No Opinion } & \multirow{2}{*}{ Total } \\
\hline & $\mathrm{F}$ & $\mathrm{R}$ & $\mathrm{F}$ & $\mathrm{R}$ & $\mathrm{F}$ & $\mathrm{R}$ & \\
\hline Yes, I Do & 77 & 29 & 112 & 42 & 36 & 13 & 225 \\
\hline No, I Don't & 9 & 3 & 12 & 4 & 24 & 9 & 45 \\
\hline \multirow[t]{3}{*}{ Total } & 86 & 32 & 124 & 46 & 60 & 22 & 270 \\
\hline & \multicolumn{7}{|c|}{ OK2 (GM Foods Contain Hormones/False) } \\
\hline & $\mathrm{F}$ & $\mathrm{R}$ & $\mathrm{F}$ & $\mathrm{R}$ & $\mathrm{F}$ & $\mathrm{R}$ & Total \\
\hline Yes, I Do & 124 & 46 & 76 & 29 & 25 & 9 & 225 \\
\hline No, I Don't & 17 & 6 & 11 & 4 & 17 & 6 & 45 \\
\hline \multirow[t]{3}{*}{ Total } & 141 & 52 & 87 & 33 & 42 & 15 & 270 \\
\hline & \multicolumn{7}{|c|}{ OK3 (By Eating Genetically Modified Foods, a Person's Genes Could Also be Changed/False) } \\
\hline & $\mathrm{F}$ & $\mathrm{R}$ & $\mathrm{F}$ & $\mathrm{R}$ & $\mathrm{F}$ & $\mathrm{R}$ & Total \\
\hline Yes, I Do & 101 & 38 & 62 & 23 & 62 & 23 & 225 \\
\hline No, I Don’t & 12 & 4 & 5 & 2 & 28 & 10 & 45 \\
\hline \multirow[t]{3}{*}{ Total } & 113 & 42 & 67 & 25 & 90 & 33 & 270 \\
\hline & \multicolumn{7}{|c|}{ OK4 (GM Foods are Larger than Ordinary Food Products/False) } \\
\hline & $\mathrm{F}$ & $\mathrm{R}$ & $\mathrm{F}$ & $\mathrm{R}$ & $\mathrm{F}$ & $\mathrm{R}$ & Total \\
\hline Yes, I Do & 117 & 43 & 80 & 30 & 28 & 10 & 225 \\
\hline No, I Don't & 14 & 5 & 12 & 5 & 19 & 7 & 45 \\
\hline Total & 131 & 48 & 92 & 35 & 47 & 17 & 270 \\
\hline
\end{tabular}

Q1: Do You Know What GM Food is?, F: Frequency, R: Ratio



Figure 5 Consumers' Agreement Level of Objective Knowledge 4

In conclusion, the correct answer ratio about the four statements that were asked to examine consumers' objective knowledge level about GM foods were found quite low.

The Multiple Correspondence Table which compares the relationship between consumers' subjective (self assessed) knowledge and objective (real) knowledge levels about GM foods is given in Table 4.

Among the consumers who stated, 'Yes, I Know What GM Food is "; $42 \%$ of them answered the first knowledge based question (OK1) correctly, 29\% of them answered the second knowledge based question (OK2) correctly, $23 \%$ of them answered the third knowledge based question (OK3) correctly, and finally $30 \%$ of them answered the fourth knowledge based question (OK4) correctly.

In conclusion; the majority of the consumers who stated, 'I know what GM food is', answered the knowledge based (objective) statements wrong. It was found that consumers were overconfident and think they know more than they actually do (Alba and Hutchinson, 2000).

Spearman Rank Correlation Analysis was conducted in order to evaluate the relationship between the knowledge level of consumers and their purchase intention about GM foods, however there wasn't any significant correlation between these two variables.

\section{Conclusion}

Usage of genetic technology in food production is still a contraversial topic. There are different results from many studies about the relationship between consumer behaviours and their knowledge level about GM foods. Obviously, there are many factors that effect consumers' behaviours regarding GM foods and knowledge level is likely the most important one among the others. There are many studies that present differences between consumers' real knowledge (objective) and self assessed knowledge (subjective) level, and look to determine the role this difference has on their behaviours.

This study was carried out in the city center of Hatay, and the aim of the study was determining consumers' subjective and objective knowledge levels about GM foods, and the effect of that knowledge level on purchase intention. According to the research results, it was found that consumers' subjective and objective knowledge levels about GM foods differ from each other, and they found themselves more knowlegeable than they really were. Among the consumers, $73 \%$ of them found themselves more or less knowledgeable about the issue; however, the correct answer ratios of the four knowledge based questions were under 50\%. Despite that there are studies in the world that present the relationship between consumers' knowledge level and their purchase intention, 
any significant relation wasn't found in this study. In this context, it could be said that besides the knowledge level, there are also other factors that effect consumers' behaviours such as risk preception, ethical reasons, and preference for naturally grown products.

\section{References}

Abdi H, Valentin D. 2007. Multiple correspondence analysis. In: Salkind, N.J. (Ed.), Encyclopedia of Measurement and Statistics. Sage, Thousand Oaks, pp. 651-657.

Aertsens J, Mondelaers K, Verbeke W, Buysse J, Huylenbroeck GV. 2010. The influence of subjective and objective knowledge on attitude, motivations and consumption of organic food. British Food Journal, Vol. 113 Iss 11 pp. $1353-1378$.

Akgönül B, Çınar D, Erem C, Halimoğlu G. 2009. Genetiği Değiştirilmiş̧ Organizmalar. Dokuz Eylül Üniversitesi. Access: http://kisi.deu.edu.tr/bulent.cavas/ders/bok1.doc.

Alba JW, Hutchinson JW. 2000. "Knowledge Calibration: What Consumers Know and What They Think They Know," Journal of Consumer Research 27 (September): 123-156.

Anonymous. 2014. T.C. Gıda Tarım ve Hayvancılık Bakanlığı. '29.05.2014 Tarihli GDO Yönetmeliği ile İlgili Basın Açıklaması". Access: https:/www.tarim.gov.tr/Sayfalar/ Detay.aspx ?OgeId $=50 \&$ Liste $=$ BasinAciklamalari

Brucks M. 1985. "The effects of product class knowledge on information search behavior", Journal of Consumer Research, Vol. 12, pp. 1-16.

Chang Yu-S, Huang Li-C. 2010. The Impact of Product Package Information on Consumer Behavior toward Genetically Modified Foods. World Academy of Science, Engineering and Technology 65, 603-607.

Churchill GA. 1995. Marketing Research: Methodologial Foundations, The Dryden Press, Harcourt Brace College Publishers, Sixth Edition.

Denison N. 1999. Harvesting the Double Helix. On Wisconsin, Fall 1999, (34-38).

Hallman WK, Hebden WC, Aquino HL, Cuite CL, Lang JT. 2003. Public perceptions of genetically modified foods: A national study of American knowledge and opinion (publication number RR 1003-004). New Brunswick, NJ: Food Policy Institute, Rutgers University.
House L, Lusk J, Jaeger S, Traill WB, Moore M, Valli C, Morrow B, Yee WMS. 2004. Objective and Subjective Knowledge: Ipmacts on Consumer Demand for Genetically Modified Foods in the United States and the European Union. AgBioForum, 7 (3): 113-123.

Jobson JD. 1991. Applied Multivariate Data Analysis. Volume I: Regression and Experimental Design. Springer Science and Business Media, New York. 110-115.

Karagöz Y, Ekici S. 2004. Sosyal Bilimlerde Yapılan Uygulamalı Araştırmalarda Kullanılan İstatistiksel Teknikler ve Ölçekler. C.Ü. İktisadi ve İdari Bilimler Dergisi, 5(1), 2543.

Karlı B, Bilgiç A, Miran B. 2008. Türkiye'de Tüketicilerin Genetiği Değiştirilmiş Gıda Algılamaları ve Bu Gıdaların Etiketlenmesi İçin Ödeme İstekliliği. VIII. Ulusal Tarım Ekonomisi Bildirileri, Gida Pazarlamas1 Kitab1, 225-237.

K1lıç AF. 2016. Uyum Analizi (Correspondence Analysis). YBS Ansiklopedi. Cilt 3, Say1 1, Mart 2016.

Klerck D, Sweeney JC. 2007. The Effect of Knowledge Types on Consumer-Perceived Risk and Adoption of Genetically Modified Foods. Psychology \& Marketing, 24(2): 171-193.

Knight AJ. 2005. Differential Effects of Perceived and Objective Knowledge Measures on Perceptions of Biotechnology. AgBioForum, 8(4): 221-227.

Koçak N, Türker T, Kılıç, S, Hasde M. 2010. Tıp Fakültesi Öğrencilerinin Genetiği Değiştirilmiş Organizmalar Hakkındaki Bilgi, Tutum ve Davranışlarının Belirlenmesi. Gülhane Tip Dergisi, 52: 198-204.

Laros FJM, Steenkamp J-BEM. 2004. Importance of Fear in the Case of Genetically Modified Food. Psychology \& Marketing, 21(11): 889-908.

Nakip M. 2006. Pazarlama Araştırmaları. Ankara: Seçkin Yayınc1lik.

Park CW, Lessig VP. 1981. "Familiarity and its Impacts on Consumer Decision Biases and Heuristics," Journal of Consumer Research, 8 (September): 223-230.

Selnes F, Gronhaug K. 1986. "Subjective and objective measures of product knowledge contrasted", Advances in Consumer Research, Vol. 13, pp. 67-71.

Uzgören N. 2007. Uyum Analizinin Teorik Esasları ve Regresyon Analizi ile Benzerliğinin Grafiksel Boyutta Karşılaştırılması. Dumlupınar Üniversitesi, Sosyal Bilimler Dergisi, Sayı 18. 